Gelanggang Pendidikan Jasmani Indonesia

\title{
PENGARUH LATIHAN LADDER DRILL TERHADAP PENINGKATAN KECEPATAN LARI PESERTA EKSTRAKURIKULER SEPAKBOLA SMA
}

\author{
Ipung Tri Cahyono ${ }^{1}$, Tatok Sugiarto ${ }^{2}$, Fahrial Amiq $^{3}$ \\ Universitas Negeri Malang, Jalan Semarang 5 Malang
}

\begin{abstract}
Info Artikel
\section{Abstrak}

Sejarah Artikel:

Diterima September 2017

Disetujui Oktober 2017

Dipublikasikan Desember 2017

\section{Keywords:}

latihan ladder drill, kecepatan lari peserta

Peserta kegiatan ekstrakurikuler sepakbola SMA Negeri 1 Pagak Kabupaten Malang memiliki masalah dalam kecepatan lari, penelitian ini bertujuan untuk meningkatkan kecepatan lari peserta. Metode yang digunakan dalam penelitian ini adalah penelitian eksperimen Bentuk rancangan penelitian yang digunakan dalam penelitian ini adalah rancangan penelitian eksperimen rancangan kelompok kontrol prates-paskates berpasangan (matching pretest-posttest control group design). Hasil pengujian hipotesis menunjukkan bahwa $\mathrm{F}$ hitung $8,24>\mathrm{F}$ tabel 4,30 untuk latihan ladder drill, sedangkan latihan konvensional memperoleh hasil $0,15<\mathrm{F}$ tabel 4,30. Selisih dari kedua kelompok diperoleh $36,439>\mathrm{F}$ tabel 4,30 . Sehingga ada pengaruh yang signifikan antara latihan ladder drill dengan latihan konvensional

\section{Abstract}

The purpose of this research is to know the influnce ogf the drill method and the method of play against the results of passing football. This research uses experimental reseacrh with matching pretest-posttest control group design designs. The subject of research is the extracurricular participants 14 MAN City Batu and extracurricular participants 14 SMKN 11 Malang. The analysis of research data using the technique of analysis of variance of one line. Hypothesis testing result obtained: (1) learning with the the treatment method drill give significant effects against the results of learning passing. (2) learning the treatment methods play a significant influence against the resultsof learning passing, and (3) there is a difference that is not significant between learning with the drill and the treatment methods of play against the result of learning passing football soccerplaying participant age of $16-17$ years.
\end{abstract}

(C) 2017 Universitas Negeri Malang

\section{PENDAHULUAN}

Permainan sepakbola telah mengalami perkembangan yang pesat sampai pada saat ini. Dahulu sepakbola dikatakan sebagai permainan yang sederhana, namun sekarang ini sepakbola dikatakan sebagai salah satu cabang permainan olahraga yang modern. Perkembangan yang pesat pada permainan sepakbola dapat dilihat dari adanya pengembangan metode-metode latihan yang diterapkan, pola permainan pada saat bertanding dan pengembangan bakat pemain sepakbola pada usia dini. Sepakbola yang modern dapat dilakukan dengan mengkombinasikan keterampilan lari dan operan bola dengan gerakan-gerakan yang sederhana disertai dengan kecepatan dan ketepatan. Oleh karena itu kecepatan lari dalam permainan sepakbola sangat dibutuhkan untuk mengejar bola saat bola di daerah permainan lawan. Dengan kecepatan lari yang maksimal, pemain dapat dengan mudah menguasai bola 
saat bola jauh di daerah lawan. Budiwanto (2011:33) menjelaskan bahwa "kecepatan adalah jarak tempuh per satuan waktu yang diukur dalam menit atau skala kuantitas, kecepatan adalah kemampuan melakukan gerakan dalam periode waktu yang pendek".

Dengan melihat hal tersebut, salah satu latihan yang dapat meningkatkan keterampilan kecepatan lari dalam sepakbola adalah dengan menggunakan latihan ladder drill (tangga latihan). Reynold (2011. The Ultimate Agility Ladder Guide. http:// footballgc.com, diakses pada tanggal 11 Desember 2015) menjelaskan bahwa "latihan ladder drill dianggap sebagai salah satu latihan yang menyenangkan, fungsional dan efektif untuk mengajarkan keterampilan gerakan-gerakan untuk meningkatkan kontraksi otot dalam kecepatan". Meskipun gerakan linier dan gerakan lateral biomekanik sederhana dalam latihan ladder drill, kombinasi gerakan latihan ini dapat menjadi kompleks dalam meningkatkan keterampilan kecepatan lari. Sedangkan menurut Ma'u dan Santoso (2014:19), "ladder adalah semacam tangga untuk melatih kekuatan dan kelincahan otot-otot kaki. Bentuk dan ukurannya bermacam-macam, ada yang rendah menempel tanah, tetapi juga ada yang tingginya $\mathrm{di}$ atas mata kaki". Untuk menghindari kejenuhan pemain sepakbola pada saat proses latihan, dikembangkan beberapa variasi-variasi dalam latihan ladder drill yaitu seperti Hop Scotch Drill, In-Out Drill dan Lateral Feet Drill.

Perkembangan yang pesat pada permainan sepakbola dapat dilihat dari adanya pengembangan metode-metode latihan yang diterapkan, pola permainan pada saat bertanding dan pengembangan bakat pemain sepakbola pada usia dini. Sepakbola yang modern dapat dilakukan dengan mengkombinasikan keterampilan lari dan operan bola dengan gerakan-gerakan yang sederhana disertai dengan kecepatan dan ketepatan. Oleh karena itu kecepatan lari dalam permainan sepakbola sangat dibutuhkan untuk mengejar bola saat bola di daerah permainan lawan. Dengan kecepatan lari yang maksimal, pemain dapat dengan mudah menguasai bola saat bola jauh di daerah lawan. Budiwanto (2011:33) menjelaskan bahwa "kecepatan adalah jarak tempuh per satuan waktu yang diukur dalam menit atau skala kuantitas, kecepatan adalah kemampuan melakukan gerakan dalam periode waktu yang pendek".

Peningkatan prestasi di bidang olahraga atau sasaran yang ingin dicapai oleh pembinaan olahraga di Indonesia membutuh- kan waktu yang lama dalam proses pembinaannya, sehingga dituntut partisipasi dari semua pihak demi peningkatan prestasi olahraga di Indonesia. Salah satu cara yang dapat dilakukan adalah melalui kegiatan ekstrakurikuler di sekolah. Menurut Mulyono (2008:187), ekstrakurikuler adalah kegiatan pembelajaran yang diselenggarakan di luar jam pelajaran biasanya yang dimaksudkan mengembangkan salah satu bidang pelajaran yang diminati oleh sekelompok peserta misalnya olahraga, kesenian, dan berbagai kegiatan keterampilan dan kepramukaan. Sedangkan menurut Lutan (1986:73), ekstrakurikuler adalah segala macam aktivitas di sekolah atau lembaga pendidikan yang dilaksanakan di luar jam pelajaran wajib bagi setiap anak dan aktivitas itu termasuk dalam kurikulum yang telah tersusun bagi suatu tingkat kelas atau sekolah.

Berdasarkan hasil pengamatan pada waktu tes awal kecepatan lari yang dilakukan oleh peserta kegiatan ekstrakurikuler sepakbola SMA Negeri 1 Pagak Kabupaten Malang dengan jarak tempuh 30 meter menggunakan rentangan ukuran kecepatan lari didapatkan 2 $(8,3 \%)$ peserta memiliki kecepatan yang baik (good), $5(20,8 \%)$ memiliki kecepatan yang cukup baik (moderate), $9(37,6 \%)$ peserta memiliki kecepatan yang rendah (low), dan 8 $(33,3 \%)$ peserta memiliki kecepatan yang lemah (poor). Dari tes awal yang telah dilakukan, dapat disimpulkan bahwa 17 (70,8\%) dari 24 peserta memiliki kecepatan yang rendah (low) dan lemah (poor). Berdasarkan hasil analisis yang terdapat pada kegiatan ekstrakurikuler sepakbola, yaitu peserta kurang memiliki kemampuan kecepatan lari.

Pada kegiatan ekstrakurikuler sepakbola SMA Negeri 1 Pagak Kabupaten Malang, pelatih kurang menerapkan variasi-variasi dalam latihan fisik, khususnya dalam hal kecepatan lari, sehingga porsi latihan yang diberikan masih kurang sesuai dengan tujuan yang ingin dicapai. Setiap pertemuan pada kegiatan ekstrakurikuler sepakbola, model latihan yang dilakukan untuk peserta kegiatan ekstrakurikuler sepakbola yaitu stretching (pemanasan), melakukan passing (mengumpan bola) berpasangan, dribbling (menggiring bola) dan dilanjutkan dengan melakukan game (permainan), sehingga peserta kegiatan ekstrakurikuler sepakbola cenderung merasa bosan pada saat latihan.

Siswa pada usia 16-18 tahun sangat cocok diterapkan latihan-latihan bervariasi dan berpotensi meningkatkan kemampuan fisik, khususnya dalam hal kecepatan dan kelincahan 
bagi seorang pemain sepakbola. Dengan metode latihan ladder drill ini diharapkan membantu dalam meningkatkan kecepatan lari pada peserta kegiatan ekstrakurikuler sepakbola SMA Negeri 1 Pagak Kabupaten Malang.

Sedangkan menurut Lutan (1986:73), ekstrakurikuler adalah segala macam aktivitas di sekolah atau lembaga pendidikan yang dilaksanakan di luar jam pelajaran wajib bagi setiap anak dan aktivitas itu termasuk dalam kurikulum yang telah tersusun bagi suatu tingkat kelas atau sekolah.

Untuk meningkatkan kecepatan lari pada peserta kegiatan ekstrakurikuler sepakbola SMA Negeri 1 Pagak Kabupaten Malang diperlukan program latihan yang disusun dan dilaksanakan dengan memperhatikan prinsipprinsip latihan dan dilaksanakan melalui penahapan, teratur, kesinambung-an, dan terus menerus tanpa berselang. Budiwanto (2012:16) menjelaskan bahwa prinsip-prinsip latihan yang perlu diperhatikan dalam proses latihan, prinsip-prisip latihan sebagai berikut. (1) prinsip beban bertambah (overload), (2) prinsip spesialisasi (specialization), (3) prinsip perorangan (individualitation), (4) prinsip variasi (variety), (5) prinsip beban meningkat bertahap (progressive increase of load), (6) prinsip perkembangan multirateral (multilteral development), (7) prinsip pulih asal (recovery), (8) prinsip reversibilitas (reversibility), (9) menghindari beban latihan berlebih (overtraining), 10) prinsip melampaui batas latihan (the abuse of training), (11) prinsip aktif partisipasi dalam latihan, dan (12) prinsip latihan menggunakan model.

Kecepatan Kecepatan adalah waktu yang dibutuhkan oleh tubuh untuk melakukan suatu kerja fisik tertentu. Kecepatan dalam olahraga merupakan inti dan sangat diperlukan agar dapat dengan segera memindahkan tubuh atau menggerakan tubuh dari suatu posisi ke posisi lainnya. Bompa (1994:273) menjelaskan "kecepatan adalah ekspresi dari serangkaian keterampilan dan kemampuan yang memungkinkan untuk kecepatan gerakan yang tinggi". Sedangkan menurut Harsono (1988:216), "kecepatan adalah kemampuan kemampuan melakukan gerakan-gerakan yang sejenis secara berturut-turut dalam waktu yang sesingkatsingkatnya".

Berdasarkan penjelasan dari para ahli, maka dapat disimpulkan bahwa kecepatan merupakan kemampuan organisme dalam upaya bergerak dari satu posisi ke posisi lainya dengan sebaik-baiknya. (5) Kelincahan (Agility) Harsono (2001:21) menjelaskan bahwa "kelincahan ialah kemampuan mengubah arah dan posisi tubuh dengan cepat dan tepat pada waktu sedang bergerak tanpa kehilangan keseimbangan dan kesadaran akan posisi tubuhnya". Sedangkan menurut Suharno (1985:32), "kelincahan adalah kemampuan untuk mengubah posisi dan arah secepat mungkin sesuai dengan situasi yang dihadapi dan dikehendaki". Scheunemann (2012:62) menjelaskan mengenai fungsi kelincahan dan koordinasi adalah sebagai berikut "(a) kemampuan teknik, taktik, dan fisik pemain secara umum (b) mencegah cedera".

Ladder drill atau tangga latihan adalah suatu alat bantu atau alat peraga latihan berbentuk seperti tangga yang bertujuan untuk meningkatkan kecepatan kaki, koordinasi kaki dan kelincahan secara keseluruhan. Tangga latihan merupakan alat peraga yang umum digunakan seluruh dunia, yang berguna membantu atlet atau pemain dalam melatih kecepatan dan koordinasi kaki.

- Reynold (2011. The Ultimate Agility Ladder Guide, http:// footballgc.com, diakses pada tanggal 11 Desember 2015) menjelaskan bahwa "latihan ladder drill dianggap sebagai salah satu latihan yang menyenangkan, fungsional dan efektif untuk mengajarkan keterampilan gerakan-gerakan untuk meningkatkan kontrakasi otot dalam kecepatan". Meskipun gerakan linier dan gerakan lateral biomekanik sederhana dalam latihan ladder drill, kombinasi latihan ini dapat menjadi kompleks untuk meningkatkan kecepatan lari. Latihan ladder drill adalah latihan dengan menggunakan alat bantu berbentuk tangga, yang bertujuan untuk meningkatkan kecepatan kaki, kelincahan koordinasi dan kecepatan secara keseluruhan. Reynolds (2011) mengatakan bahwa. "Untuk menghindari kejenuhan dalam proses latihan ladder drill ini, terdapat beberapa variasi-variasi latihan ladder drill, diantaranya latihan steady state (latihan ini fokus pada kecepatan daya tahan dan memanfaatkan irama yang konstan sepanjang tangga latihan), latihan burst drill (latihan ini fokus pada kemampuan untuk menghidupkan ledakan cepat gerakan kaki) dan latihan elastic response drill (latihan ini fokus pada peningkatan kecepatan reaktif komponen kaki bagian bawah".

Latihan ladder drill (tangga latihan) ini
bekerja seberapa cepat dapat mengkoordinasikan pola gerak kaki yang berbeda. Latihan gerakan ini menekankan bentuk dan kualitas dari pada beban latihan kaki. Latihan ladder drill (tangga latihan) dilakukan untuk mengembangkan kecepatan dan kegesitan dalam olahraga yang membutuhkan perubahan konstan dalam 
gerakan. Latihan ladder drill (tangga latihan) dapat efektif sebagai stretching (pemanasan) untuk melatih atau meningkatkan kecepatan. Tindakan atau latihan berulang-ulang terhadap kecepatan dan kelincahan kaki dapat menjadi efektif untuk otot, elastisitas tendon dan juga komponen cardio pada saat berlari.

Latihan ladder drill (tangga latihan) melibatkan perubahan yang cepat dari arah gaya atau gerakan dari satu posisi ke posisi yang lain. Latihan ladder drill (tangga latihan) akan bekerja dengan baik sebagai gerakan stretching (pemanasan) untuk meningkatakan kecepatan dalam melakukan kecepatan lari dalam permainan sepakbola. Gerakan latihan ladder drill (tangga latihan) dimulai dengan pemain berdiri pada garis start di belakang kotak tangga, selanjutnya gerakan kaki meloncat melawati kotak-kotak tangga yang telah ditentukan dan gerakan kaki pada setiap latihannya berbeda. Gerakan ini ada yang menggunakan kedua kaki secara bersamaan dan juga ada gerakan kedua kaki yang dilakukan secara bergantian. Latihan ladder drill (tangga latihan) menekankan pada koordinasi dan kelincahan kaki dalam melawati rintangan pada kotak-kotak tangga dan kecepatan gerakan kaki dalam melawati kotak-kotak tersebut.

Latihan ladder drill ini dilakukan dalam setiap kali pertemuan dalam latihan ekstrakurikuler sepakbola. Pe-laksanaan latihan ladder drill dilakukan setelah peserta ekstrakurikuler sepak-bola melakukan pema-nasan/stretching. Dan pemain harus mampu berlari ratus-an meter dalam satu pertandingan, hampir menyamai kecepatan sprinter dan menanggapi berbagai perubahan situasi permainan dengan cepat. Harsono (1988:216) "kecepatan bukan hanya berarti menggerakkan seluruh tubuh dengan cepat, akan tetapi dapat pula terbatas dalam menggerakkan anggota-anggota tubuh dalam waktu sesingkat-singkatnya". Bompa (2000:62). "Kecepatan (speed) penting bagi atlet, sebab mayoritas para atlet haruslah berlari, bergerak, bereaksi ataupun ganti arah dengan cepat. Kecepatan mencakup tiga unsur, termasuk waktu reaksi, waktu bergerak dan kecepatan berlari".

Dari beberapa pernyataan ahli dapat disimpulkan bahwa kecepatan adalah kemampuan berpindah dari satu tempat ke tempat lain dalam waktu sesingkat-singkatnya. Dalam permainan sepakbola juga membutuhkan kecepatan berlari untuk memaksimalkan ruang terbuka, misalnya untuk melakukan penyerangan dengan teknik running with the ball.
Latihan running with the ball juga berpengaruh terhadap prestasi menggiring bola dan latihan zig-zag run berpengaruh terhadap kecepatan lari pemain (Saputro, 2015). Dapat disimpulkan bahwa unsur kecepatan, koordinasi dan kelincahan terdapat dalam latihan running with the bal.

Berdasarkan latar belakang yang telah diuraikan, peneliti telah melakukan penelitian dengan judul "pengaruh latihan ladder drill terhadap peningkatan kecepatan lari peserta kegiatan ekstrakurikuler sepakbola sma negeri 1 pagak kabupaten malang".

Tujuan penelitian ini adalah: (1) Untuk mengetahui pengaruh latihan ladder drill terhadap peningkatan kecepatan lari peserta kegiatan ekstrakurikuler sepakbola SMA Negeri 1 Pagak Kabupaten Malang. (2) Untuk mengetahui pengaruh latihan konvensional terhadap peningkatan kecepatan lari peserta kegiatan ekstrakurikuler sepakbola SMA Negeri 1 Pagak Kabupaten Malang. (3) Untuk mengetahui perbedaan pengaruh antara latihan ladder drill dengan latihan konvensional terhadap peningkatan kecepatan lari peserta kegiatan ekstrakurikuler sepakbola SMA Negeri 1 Pagak Kabupaten Malang

\section{METODE}

Jenis penelitian pada kasus ini adalah penelitian eksperimental. Rancangan kelompok kontrol prates-paskates berpasangan (matching pretest-posttest control group design)" (sukmadinata, 2013:207).

Variabel yang diteliti dalam pene-litian ini adalah latihan ladder drill sebagai variabel bebas dan kecepatan lari sebagai variabel terikat. Dalam penelitian ini langkah awal yang dilakukan adalah melakukan pre-test $\left(\mathrm{o}_{1}\right)$, kemudian kelompok eksperimen diberikan perlakuan (x) selama 18 kali pertemuan. Sedangkan untuk kelompok kontrol tidak diberikan perlakuan (x). Kemudian langkah selanjutnya melakukan post-test $\left(\mathrm{o}_{2}\right)$. Selanjutnya membandingkan perubahan yang terjadi pada testi yang diberi perlakuan (x) pada kelompok eksperimen dengan perubahan yang terjadi pada kelompok kontrol (-).

Populasi penelitian ini adalah seluruh peserta kegiatan ekstrakurikuler sepakbola sma negeri 1 pagak kabupaten malang dengan usia 16 tahun sampai 18 tahun yang berjumlah 30 peserta. Populasi ini mempunyai beberapa sifat yang sama, yaitu berjenis kelamin laki-laki dan usia sebaya 16 tahun sampai 18 tahun. 
Sampel dalam penelitian ini adalah peserta kegiatan ekstrakurikuler sepakbola sma negeri 1 pagak kabupaten malang yang berjumlah 24 peserta dan pengambilan sampel menggunakan teknik simple random sampling berjumlah 24 peserta. Dari 24 peserta populasi, 12 peserta sampel masuk dalam kelompok eksperimen dan 12 peserta sampel masuk kelompok kontrol..

Instrumen yang digunakan penelitian ini berupa instrumen tes kecepatan lari ditujukan pada peserta kegiatan ekstrakurikuler sepakbola sma negeri 1 pagak kabupaten malang. Dengan menggunakan linier sprint test (kecepatan lari 30 meter) untuk mengukur kecepatan dalam melakukan lari sprint.

Teknik pengumpulan data yang digunakan adalah teknik observasi, eksperimen, dan teknik pengukuran berbentuk tes kecepatan lari menggunakan linier sprint test. Teknik observasi digunakan untuk memperoleh data tes awal dan akhir. Teknik eksperimen digunakan untuk memberi perlakuan terhadap testi dan teknik pengukuran digunakan untuk memperoleh data hasil tes awal dan tes akhir kecepatan lari.

Data yang diperoleh dari hasil linier sprint test dari kelompok eksperimen dan kelompok kontrol termasuk jenis data rasio. Dengan pertimbangan jenis data tersebut dan tujuan penelitian, maka data yang terkumpul dianalisis dengan menggunakan statistika inferensial. Berdasarkan hipotesis peneliti yang telah dirumuskan, maka teknik statistika yang digunakan berupa teknik analisis varian satu jalur. Sebelum dilakukan pengujian hipotesis dengan anava, terlebih dahulu dilakukan data uji persyaratan analisis yaitu uji normalitas dan homogenitas.

Teknik yang digunakan untuk analisis uji normalitas data adalah teknik lilliefors. Data yang dilakukan pengujian normalitas adalah skor prestasi antara tes awal dari masingmasing kelompok dan skor prestasi antara tes akhir dari masing-masing kelompok. Sedangkan pengujian homogen diperlukan sebelum analisis varians dilakukan, pengujian dilakukan dengan menggunakan uji f. Data yang dilakukan pengujian homogenitas adalah skor prestasi antara tes awal dari masing-masing kelompok dan skor prestasi antara tes akhir dari masing-masing kelompok. Perbandingan harga $\mathrm{f}$ hitung dengan $\mathrm{f}$ tabel pada taraf signifikasi $\alpha=$ 0,05 . Data dinyatakan homogen apabila $\mathrm{f}$ hitung < f tabel, uji homogenitas ini dilakukan dengan taraf signifikasi $\alpha=0,05$ (sugiyono, 2008:175).

\section{HASIL}

Data prestasi kecepatan lari peserta ektrakurikuler sepakbola SMA Negeri 1 Pagak Kabupaten Malang yang digunakan untuk analisis adalah skor yang berasal dari skor tes awal (pretest) dan tes akhir (postest) kecepatan lari peserta ektrakurikuler sepakbola SMA Negeri 1 Pagak Kabupaten Malang. Data yang diperoleh merupakan data yang dihasilkan dari pertemuan pertama di lapangan sebelum dikelompokkan dalam kelompok eksperimen dan kelompok kontrol dan diranking mulai dari tertinggi sampai terendah kemudian baru dikelompokkan. Untuk data yang pertama adalah prestasi skor awal kecepatan lari peserta kelompok latihan ladder drill peserta ektrakurikuler sepakbola SMA Negeri 1 Pagak Kabupaten Malang. Berdasarkan hasil perhitungan yang telah dilakukan, diketahui bahwa kecepatan lari kelompok latihan ladder drill mendapatkan rata-rata sebesar 4,44, simpangan baku sebesar 0,11, dengan rentangan skor antara 4,21 sampai dengan 4,59.

Dari data yang diperoleh dapat dilihat 8 orang $(66,7 \%)$ memperoleh skor di atas ratarata dan 4 orang $(33,3 \%)$ memperoleh skor di bawah rata-rata.

Untuk data kedua adalah prestasi skor akhir kecepatan lari peserta kelompok latihan ladder drill peserta ektrakurikuler sepakbola SMA Negeri 1 Pagak Kabupaten Malang. Berdasarkan hasil perhitungan yang telah dilakukan, diketahui bahwa keterampilan skor akhir kecepatan lari kelompok latihan ladder drill mendapatkan rata-rata sebesar 4,29, simpangan baku sebesar 0,10, dengan rentangan skor antara 4,21 sampai dengan 4,59. Dari data yang diperoleh dapat dilihat 10 orang $(83,3 \%)$ memperoleh skor di atas ratarata dan 2 orang $(16,7 \%)$ memperoleh skor di bawah rata-rata.

Data ketiga adalah prestasi keterampilan skor awal kecepatan lari kelompok latihan komando peserta ektrakurikuler sepakbola SMA Negeri 1 Pagak Kabupaten Malang. Berdasarkan hasil perhitungan yang telah dilakukan, diketahui bahwa keterampilan skor awal kecepatan lari kelompok latihan komando mendapatkan rata-rata sebesar 4,44, simpangan baku sebesar 0,11, dengan rentangan skor antara 4,22 sampai dengan 4,58.

Dari data yang diperoleh dapat dilihat 4 orang $(33,3 \%)$ memperoleh skor di atas ratarata dan 8 orang $(66,7 \%)$ memperoleh skor di bawah rata-rata.

Data keempat adalah prestasi keterampilan skor akhir kecepatan lari kelompok 
latihan komando peserta ektrakurikuler sepakbola SMA Negeri 1 Pagak Kabupaten Malang. Berdasarkan hasil perhitungan yang telah dilakukan, diketahui bahwa keterampilan skor akhir kecepatan lari kelompok latihan komando mendapatkan rata-rata sebesar 4,44, simpangan baku sebesar 0,10, dengan rentangan skor antara 4,21 sampai dengan 4,60.

Dari data yang diperoleh dapat dilihat 3 orang $(25 \%)$ memperoleh skor di atas rata-rata dan 9 orang $(75 \%)$ memperoleh skor di bawah rata-rata. Pada hasil tes kecepatan lari pemain yang digunakan untuk analisis adalah skor tes awal (pretest) dan tes akhir (posttest) kecepatan lari peserta ektrakurikuler sepakbola SMA Negeri 1 Pagak Kabupaten Malang. berupa data deskriptif data analisis mean, median, nilai maksimal, nilai minimal dan standar deviasi dari hasil tes kecepatan lari.

Berdasarkan hasil perhitungan yang telah dilakukan diketahui hasil tes awal kecepatan lari peserta kegiatan ekstrakurikuler sepakbola SMA Negeri 1 Pagak Kabupaten Malang kelompok ladder drill rata-rata hasil tes sebesar 4,44 detik standar deviasi sebesar 0,11 detik . Hasil tes akhir kelompok ladder drill, rata-rata hasil tes sebesar 2,29 detik standar deviasi 0,10 detik.

Sedangkan kelompok komando rata-rata hasil tes awal sebesar 4,44 detik standar deviasi 0,11 detik dan hasil rata-rata tes akhir sebesar 4,44 detik standard deviasi sebesar 0.10 detik.

Sebelum dilakukan pengujian hipotesis dengan menggunkan analisis varian satu jalur, terlebih dahulu harus dilakukan uji persyaratan yaitu berupa uji normalitas dan uji homogenitas. Uji normalitas pada penelitian ini menggunakan rumus pengujian Lilliefors (Nurrochmah, 2005:20-21). Berdasar-kan hasil pengujian normalitas data dengan menggunakan uji Lilliefors pada taraf signifikansi $(\alpha)=$ 0,05, menunjukkan hasil sebagai berikut.

Berdasarkan hasil perhitungan uji normalitas yang ditunjukkan pada Tabel 2, uji normalitas keterampilan skor awal kecepatan lari dari kelompok latihan ladder drill diperoleh harga Lhitung 0,0913 < Ltabel dengan taraf signifikansi $\alpha=0,05=0,242$, uji normalitas keterampilan skor akhir kecepatan lari dari kelompok latihan ladder drill diperoleh harga Lhitung $0,0660<$ Ltabel dengan taraf signifikansi $\alpha=0,05=0,242$, uji normalitas keterampilan Skor awal kecepatan lari dari kelompok latihan komando diperoleh harga Lhitung $0,0487<$ Ltabel dengan taraf signifikansi $\alpha=0,05=0,242$ dan uji normalitas keterampilan skor akhir kecepatan lari dari kelompok latihan komando diperoleh harga
Lhitung $0,10724<$ Ltabel dengan taraf signifikansi $\alpha=0,05=0,242$. Maka dari itu dapat disimpulkan bahwa keterampilan skor awal dan skor akhir kecepatan lari dari masingmasing kelompok berdistribusi normal.

Selanjutnya pengujian homogenitas data. Uji homogenitas digunakan untuk mengetahui apakah hasil yang diambil dari tes awal (pretest) dan tes akhir (postest) mempunyai varian data yang sama atau tidak.

Berdasarkan hasil perhitungan uji homogenitas sebagaimana ditunjukkan dalam Tabel 3 diperoleh harga Fhitung untuk seluruh kelompok latihan lebih kecil jika dibandingkan dengan Ftabel taraf signifikansi $\alpha=0.05$. Dengan demikian dapat disimpulkan bahwa seluruh kelompok berasal dari populasi yang homogen.

Setelah dilakukannya uji persyaratan, kemudian dilakuan perhitungan uji hipotesis dengan menggunakan teknik analisis varian satu jalur (one way anova) dilakukan dengan taraf signifikasi $\alpha=0.05$. Untuk uji hipotesis pertama dengan menggunakan analisis varian satu jalur terhadap skor prestasi tes awal dengan tes akhir kecepatan lari peserta kelompok latihan ladder drill. Diperoleh harga $\mathrm{F}$ hitung 5,54> F tabel dengan taraf signifikansi $\alpha$ $=0,05=4,30$. Disimpulkan bahwa ada perbedaan pengaruh yang signifikan antara hasil keterampilan skor awal dengan skor akhir kecepatan lari dari hasil kelompok latihan ladder drill.

Uji hipotesis kedua dengan menggunakan analisis varian satu jalur terhadap skor prestasi tes awal dengan tes akhir kecepatan lari pemain kelompok latihan komando. diperoleh harga $\mathrm{F}$ hitung untuk skor prestasi kecepatan lari lebih kecil jika dibandingkan dengan $\mathrm{F}$ tabel pada taraf signifikansi $\alpha=0,05$. Oleh karena $F$ hitung $0,15<\mathrm{F}$ tabel 4,30, maka hipotesis nihil diterima dan hipotesis kerja yang menyatakan pengaruh latihan komando terhadap keterampilan kecepatan lari peserta ditolak, dengan demikian dapat disimpulkan bahwa tidak ada pengaruh yang signifikan antara hasil skor awal dengan skor akhir pada kelompok komando.

Uji hipotesis ketiga dengan menggunakan analisis varian satu jalur terhadap selisih skor prestasi tes awal dan tes akhir masingmasing kelompok terhadap kecepatan lari pemain. Diperoleh harga Fhitung sebesar $36,439>$ Ftabel taraf signifikasi $(\alpha=0,05)=$ 4,30. Dengan demikian pada hipotesis ketiga dapat disimpulkan bahwa ada perbedaan pengaruh yang signifikan antara selisih prestasi skor awal dengan skor akhir kelompok latihan 
ladder drill yang diberikan peneliti dengan kelompok latihan komando yang diberikan oleh pelatih

\section{PEMBAHASAN}

Hasil analisis pengaruh antara variabel bebas terhadap variabel terikat dalam pengujian hipotesis perlu dikaji lebih lanjut dengan memberikan interpretasi keterkaitan antara hasil analisis yang dicapai dengan teori-teori yang mendasari penelitian ini. Penjelasan ini diperlukan untuk mengetahui kesesuaian teoriteori yang dikemukakan dengan hasil penelitian yang diperoleh. Adapun penjelasan untuk memberikan kejelasan keterkaitan variabel bebas terhadap variabel terikat adalah sebagai berikut. Hasil uji hipotesis pertama setelah dilaksanakan penelitian yang diawali dengan pengaruh latihan ladder drill terhadap peningkatan kecepatan lari peserta ektrakurikuler sepakbola SMA Negeri 1 Pagak Kabupaten Malang.

Berdasarkan hasil/skor kecepatan lari yang dilakukan pada kelompok latihan ladder drill, diketahui latihan ini ada pengaruh yang signifikan terhadap kecepatan lari pemain. Berdasarkan hasil uji hipotesis analisis varians yang dilakukan dengan menggunakan uji $\mathrm{F}$ skor keterampilan skor awal dengan skor akhir pada kelompok eksperimen diperoleh hasil uji signifikasi yaitu, Fhitung > Ftabel, maka dari itu dapat disimpulkan bahwa ada perbedaan yang signifikan antara hasil keterampilan skor awal dengan skor akhir kelompok latihan ladder drill. Ditunjukkan dari peningkatan rata-rata skor awal dan rata-rata skor akhir, hal itu berarti menunjukkan adanya pengaruh yang signifikan.

Bompa (2009:272) menyatakan bahwa "kecepatan dan kelincahan, dan daya tahan kecepatan adalah kemampuan penting yang dapat mempengaruhi kinerja dalam berbagai olahraga. Kekuatan ini berkaitan dan sebagian besar tergantung pada kekuatan otot atlet. Mengintegrasikan kecepatan, kelincahan, dan kecepatan, latihan daya tahan ke dalam rencana pelatihan tahunan dan memanipulasi variabel pelatihan khusus dapat mengoptimalkan kapasitas performa."

Peranan model yang digunakan juga sangat mempengaruhi. Menurut Budiwanto (2012:28), dengan menggunakan model, pelatih berusaha mengorganisasi latihan dalam cara yang obyektif, metode dan isi yang mirip dengan situasi pertandingan. Suatu model mempunyai kekhususan untuk setiap per- orangan atau tim. Pelatih atau atlet akan menghadapi tantangan umum meniru model latihan untuk keberhasilan atlet atau tim. Kecepatan lari peserta ektrakurikuler sepakbola SMA Negeri 1 Pagak Kabupaten Malang meningkat dari sebelumnya, hal itu dikarenakan pemain kelompok latihan ladder drill melakukan latihan yang di dalamnya mengandung unsur kecepatan, koordinasi dan kelincahan yang terdapat dalam latihan ladder drill.

Hasil uji hipotesis kedua adalah pengaruh latihan komando terhadap peningkatan kecepatan lari peserta kegiatan ekstrakurikuler sepakbola SMA Negeri 1 Pagak Kabupaten Malang. Berdasarkan hasil skor kecepatan lari yang dilakukan pada kelompok latihan komando ternyata latihan ini tidak ada pengaruh yang signifikan terhadap kecepatan lari pemain. Berdasarkan hasil uji hipotesis analisis varians yang dilakukan dengan menggunakan uji $\mathrm{F}$ skor keterampilan skor awal dengan skor akhir pada kelompok latihan Komando diperoleh hasil uji signifikasi yaitu, Fhitung < Ftabel, maka dari itu dapat disimpulkan bahwa tidak ada perbedaan yang signifikan antara hasil keterampilan skor awal dengan skor akhir kelompok latihan komando. Ditunjukkan dari penurunan rata-rata skor awal dan rata-rata skor akhir, hal itu berarti menunjukkan tidak adanya pengaruh yang signifikan. Hal tersebut dikarenakan latihan komando tidak dikhususkan untuk latihan kecepatan lari pemain.

Bompa (2009:205) menyatakan bahwa "latihan harus diatur dan direncanakan dengan baik sehingga dapat menjamin tercapainya tujuan dari latihan. Proses perencanaan latihan menunjukkan suatu yang diorganisasi dengan baik, sehingga dapat membantu para atlet untuk mencapai hasil yang lebih baik berdasarkan latihan dan prestasinya".

Harsono (1988:121) menyatakan bahwa "variasi-variasi latihan yang dikreasi dan diterapkan secara cerdik akan dapat menjaga terpeliharanya fisik maupun mental atlet, sehingga dengan demikian timbulnya kebosanan berlatih sejauh mungkin dapat dihindari. Atlet selalu membutuhkan variasi dalam latihan. Oleh karena itu pelatih wajib dan patut menciptakannya dalam latihan-latihan". Maka dari itu, terjadinya sedikit penurunan kecepatan lari peserta kegiatan ekstrakurikuler sepakbola SMA Negeri 1 Pagak Kabupaten Malang kelompok latihan komando ini dikarenakan peserta dari kelompok latihan komando melakukan latihan yang diberikan pelatih hanya sedikit menekankan pada latihan fisik, 
tetapi lebih banyak menekankan pada latihan teknik, sehingga latihan fisik seperti kecepatan dan kelincahan sering diabaikan oleh pelatih. Selain itu program latihan tidak tersusun secara sistematis, sehingga peningkatan kecepatan pemain tidak maksimal.

Hasil uji hipotesis ketiga yaitu perbedaan pengaruh antara latihan ladder drill dengan latihan komando terhadap peningkatan kecepatan lari peserta ektrakurikuler sepakbola SMA Negeri 1 Pagak Kabupaten Malang. Berdasarkan hasil skor kecepatan lari antara kelompok eksperimen dengan kelompok konvensional, dapat disimpulkan bahwa latihan ladder drill memberikan pengaruh yang lebih baik dibandingkan dengan latihan komando, hal ini dibuktikan dengan adanya perbedaan rata-rata yang didapatkan oleh masing-masing kelompok. Kelompok ladder drill peningkatan rata-rata, sedangkan kelompok konvensional mengalami penurunan rata-rata.

Sesuai dengan hasil peningkatan kecepatan lari pemain tersebut, maka dapat disimpulkan bahwa latihan ladder drill lebih baik dalam meningkatkan kecepatan lari pemain dibandingkan dengan latihan komando. Selanjutnya berdasarkan hasil uji hipotesis analisis varians satu jalur (one way anova), skor kecepatan lari pemain antara kelompok eksperimen dengan kelompok kontrol yang menggunakan uji $\mathrm{F}$, diperoleh $\mathrm{F}$ hitung $>\mathrm{F}$ tabel pada taraf signifikansi $\alpha=0,05$, maka dapat disimpulkan bahwa tidak ada pengaruh yang signifikan antara latihan kecepatan dengan latihan komando. Latihan ladder drill dapat meningkatan kecepatan dribbling pemain sepakbola (Setiawan, 2011).

Dari hasil penelitian dan hasil analisis data yang telah dilakukan, dapat diperoleh kesimpulan sebagai berikut: (1) Ada perbedaan antara latihan ladder dengan latihan konvensional terhadap prestasi keterampilan dribbling bola pada pemain Sekolah Sepakbola (SSB) Batu Putra usia 14-15 tahun di Kota Batu. Pengaruh latihan ladder lebih memberikan pengaruh yang lebih tinggi dari pada latihan konvensional. (2) Latihan ladder dapat memberikan pengaruh terhadap peningkatan keterampilan dribbling bola pada permainan sepakbola pada pemain Sekolah sepakbola (SSB) Batu Putra usia 14-15 tahun di Kota Batu. (3) Latihan konvensional juga memberikan pengaruh terhadap peningkatan keterampilan dribbling bola pada permainan sepakbola pada pemain Sekolah Sepakbola (SSB) Batu Putra usia 14-15 tahun

\section{KESIMPULAN}

dari hasil penelitian dan hasil analisis data yang telah dilakukan, dapat diperoleh kesimpulan sebagai berikut: (1) latihan ladder drill berpengaruh secara signifikan disbandingkan latihan konvensional terhadap peningkatan kecepatan lari siswa ekstrakurikuler sepakbola sma negeri 1 pagak kabupaten malang. (2) latihan konvensional tidak berpengaruh yang signifikan terhadap peningkatan kecepatan lari peserta kegiatan ekstrakurikuler sepakbola sma negeri 1 pagak kabupaten malang. (3) latihan ladder drill lebih baik secara signifikan terhadap peningkatan kecepatan lari dibandingkan dengan latihan konvensional untuk peserta kegiatan ekstrakurikuler sepakbola sma negeri 1 pagak kabupaten malang.

\section{DAFTAR PUSTAKA}

Saputro A.B, 2015 Pengaruh Latihan Running With The Ball Terhadap Peningkatan Kecepatan Lari Pemain Persatuan Sepakbola Djagung Kota Malang, Malang: Universitas Negeri Malang.

Arikunto, Suharsimi. 2010. Prosedur Penelitian Suatu Pendekatan Praktik. Jakarta: Rineke Cipta.

Bangsbo, Jens dan Maghni Mohr. 2012. Fitness Testing In Football. Bagsvaerd: AFC.

Budiwanto, S. 2012. Metodologi Kepelatihan Olahraga. Malang: UM Press.

Budiwanto, S. 2004. Teknik Analisis Statistika. Malang: UM Press.

Budiwanto, Setyo. 2011. Metodologi Kepelatihan Olahraga. Malang: Universitas

Negeri Malang (UM PRESS).

Bompa, Tudor O. Dkk. 2009. Periodization Theory and Methodology of Training 5th Edition. Colorado: Human Kinestis Publisher.

Bompa, Tudor. 1994. Theory and Methodologi of Training. The Key to Athletik Performance. Toronto, Ontario Canada: Kendall/Hunt Publishing Company.

Giffort, C, 2003. Sepakbola Panduan Lengkap Untuk Permainan Yang Indah. Jakarta: Erlangg. 
Harsono. 1988. Coaching dan Aspek-aspek Psikologi dalam Coaching. Jakarta: Direktorat Jendral Pendidikan Tinggi.

Harsono. 2001. Latihan Kondisi Fisik. Bandung: Pusat Ilmu Olahraga KONI Pusat.

Kosasih. 1985. Olahraga Teknik dan Program Latihan. Jakarta: Akademi Pressindo.

Luxbacher, J.A. 1998. Sepak Bola. Jakarta: PT. Raja Grafindo Persada.

Lutan, Rusli. 1986. Pengelolaan Interaksi Belajar Mengajar Intrakurikuler, Kokurikuler, dan Ekstrakurikuler. Jakarta: Karunika Jakarta Universitas Terbuka 1986 ekstrakurikuler.

Mu'arifin. 2009. Dasar-dasar Pendidikan Jasmani dan Olahraga. Malang: Universitas Negeri Malang (UM Press).

Ma`u, Mellius dan J. Santoso. 2014. Teknik Dasar Bermain Sepak Bola. Yogyakarta: Cakrawala.

Mulyono, M A. 2008. Managemen Administrasi \& Olahraga Pendidikan. Jogjakarta: ArRuzz Media.

Mukholid, Agus. 2007. Pendidikan Jasmani dan Kesehatan. Surakarta: Yudhistira.

Nurrochmah S. 2005. Prosedur Analisis Uji Persyaratan Dalam Statistika Inferensial. Laboratorium Ilmu? Keolahragaan Fakultas Ilmu Keolahragaan Universitas Negeri Malang.

Reynold, Tony. 2011. The Ultimate Agility Ladder Guide. (Online),

(http:// footballgc.com, diakses pada tanggal 11 Desember 2015).

Sugiyono. 2010. Metode Penelitian Kuantitatif Kualitatif dan R\&D. Bandung: Alfabeta.

Sugiyono. 2008. Metode Penelitian Pendidikan R\&D. Bandung: Alfabeta.

Sukmadinata, N.S. 2013, Metode Penelitian Pendidikan. Bandung: PT REMAJA ROSDAKARYA.

Sudjana. 2005, Metode Statistika Edisi 6. Bandung: TARSITO.

Winarno, M.E. 2011. Metodologi Penelitian dalam Pendidikan Jasmani. Malang: Universitas Negeri Malang Fakultas Ilmu Pendidikan.
Wiley. J \& Sons. 2010. Analysis of Ordinal Categorial Data. Canada (Online), (http:// books. google. co. id, diakses pada tanggal 23 Januari 2015). 